\title{
Tromboza de sinus venos transvers stâng asociată meningitei pneumococice la copil - diagnostic intuitiv vs. cognitiv
}

\author{
Maria Obreja' ${ }^{1}$, Liliana Vlad', Radu Miftode ${ }^{2}$, Alexandr Ceasovschih ${ }^{3}$, Egidia Miftode ${ }^{1,2}$ \\ ${ }^{1}$ Spitalul de Boli Infecţioase „Sfânta Parascheva“, Iaşi, România \\ 2Universitatea de Medicină şi Farmacie „Grigore T. Popa", Iaşi, România \\ ${ }^{3}$ Clinica a II-a de Medicină Internă, Spitalul Clinic de Urgenţă „Sf. Spiridon“, Iaşi, România
}

\begin{abstract}
REZUMAT
Introducere. Tromboza venoasă cerebrală (TVC) este o afecţiune cerebrovasculară rară cu multiple etiologii. Diagnosticul de TVC este în general obişnuit trecut cu vederea sau întârziat din cauza simptomatologiei extrem de variate, modalităţilor de debut şi semnelor neuroimagistice; mai mult, în peste $15 \%$ din cazuri, nu poate fi decelată o cauză, rezultatul individual poate fi greu de prezis, iar boala se poate complica în pofida tratamentului anticoagulant.

Material şi metode. Prezentăm un caz tipic de meningită care în ziua 10 de boală asociază o simptomatologie nu foarte tipică ce pledează spre TVC.

Rezultate. Examenele imagistice nu pot nici infirma, nici confirma prezenţa trombului. Un caz a cărui evoluţie se agravează progresiv şi pentru care nu există susţinerea imagistică de a aborda o anumită conduită terapeutică îngreunează decizia terapeutică a medicului.

Discuţii. Problematica ridicată se concentrează pe ipoteza conform căreia dacă medicaţia anticoagulantă poate aduce un beneficiu pacientului sau, dimpotrivă, un prejudiciu medicului curant aflat în improbabilitate diagnostică, printr-o evoluţie ulterioară nefavorabilă a stării clinice a pacientului.

Concluzii. Raţionamentul creierului uman format în ani de experienţă nu poate fi încă tehnologizat, cu atât mai puţin înlocuit de vreun robot, iar existenţa unor seturi de reguli de tratament, care nu pot acoperi niciodată varietatea de particularităţi ce se poate întâlni în practică, trebuie pusă întotdeauna la îndoială.
\end{abstract}

Cuvinte cheie: tromboză cerebrală venoasă, meningită, convulsii, computer-tomograf, diagnostic

\section{INTRODUCERE}

Tromboza venoasă cerebrală (TVC) este o afecțiune cerebrovasculară ce afectează 5 persoane la 1.000 .000 şi reprezintă $0,5 \%$ din totalul accidentelor vasculare cerebrale (1). Este mai puțin frecventă decât accidentul vascular ischemic sau hemoragia intracerebrală. Incidența sa este comparabilă cu cea a meningitelor acute bacteriene la adulți (2). TVC a fost prima dată recunoscută la începutul secolului al 19-lea. În general afectează sinusul sagital superior şi determină deficite focale alternative sau bilateral, convulsii şi comă, care de obicei conduc la moarte.
În ultimii 25 de ani neuroimagistica a ajutat la diagnosticarea precoce a patologiei, fapt care a modificat informațiile curente care există despre această boală. TVC este recunoscută ca o boală neinfecțioasă cu variate manifestări clinice şi răspuns favorabil, cu mortalitate cu mult sub 10\%. Rezonanța magnetică şi angiografia sunt cele mai bune metode de diagnostic, iar heparina reprezintă prima intenție în tratament (1).

\section{PREZENTAREA CAZULUI}

Prezentăm cazul unui copil în vârstă de 10 ani, de sex masculin, din mediul rural, care se prezintă 
în Departamentul de Primire Urgențe Pediatrie pentru febră, tuse productivă, cefalee frontală, tulburări de vedere, vertij, vărsături, dureri abdominale. Debutul a fost insidios pe parcursul celor 5 zile ce au precedat internarea, cu agravare în ultima zi prin lipsa răspunsului la stimuli asociată cu pierderea conştienței. Din antecedentele personale patologice trebuie menționate infecții recurente de tract respirator, sindrom de instabilitate vezicală, anemie feriprivă şi hipotrofie staturo-ponderală.

S-a efectuat un examen computer-tomograf (CT) în secția de neurologie a spitalulul de copii, la care s-a decelat edem cerebral difuz. Examenele biologice au relevat sindrom inflamator asociat cu leucocitoză cu neutrofilie $(\mathrm{GA}=33.490 / \mathrm{mmc}$ cu $\mathrm{PMN}=93.1 \%, \mathrm{Fbg}=467 \mathrm{mg} / \mathrm{dl})$. Contextul clinic coroborat cu datele de laborator şi examenul CT nespecific pentru o afecțiune neurochirurgicală au ridicat suspiciunea unei meningite, motiv pentru care pacientul a fost direcționat în spitalul de Boli Infecţioase.

Clinic la internare s-a constatat o stare generală sever influențată, febril, comă scor Glasgow 4-5, intens sindrom de contractură meningiană: Kernig I, Brudzinski al cefei şi contralateral, congestie facială, tahicardie, incontinență urinară. S-a efectuat puncție lombară şi s-a decelat lichid cefalorahidian (LCR) tulbure cu $960 \mathrm{ecn} / \mathrm{mmc}$, dintre care $\mathrm{PMN}=97 \%$, cu prezența $S$. pneumoniae în cultură.

S-a instituit tratament cu vancomicină şi cefotaxim, sensibilitatea la acestea fiind ulterior confirmată prin antibiogramă. Din cauza apariției unei erupții eritematoase la nivelul faciesului şi toracelui ca urmare a administrării rapide de vancomicină, s-a remaniat schema terapeutică înlocuindu-se vancomicina cu rifampicina (conform antibiogramei). A treia zi de la internare s-a efectuat o nouă puncție lombară care a relevat LCR intens tulbure cu $3.400 \mathrm{ecn} / \mathrm{mmc}$, dintre care $\mathrm{PMN}=98 \%$. S-a întrerupt tratamentul antibiotic cu cefotaxim şi s-a introdus meropenem.

După alte două zile, pacientul a instalat deficit neuromotor parțial hemicorp superior drept, cu mişcări necontrolate la nivelul membrului superior drept, absența reflexelor osteotendinoase, semnul Babinski pozitiv. S-a ridicat suspiciunea unui abces cerebral, motiv pentru care s-a efectuat un nou examen CT. Diagnosticul a fost: „observație tromboză de sinus transvers stâng imediat după origine şi moderat edem cerebral difuz", fără indicație neurochirurgicală. În pofida incertitudinii diagnostice în urma examenului CT s-a instituit tratament anticoagulant cu enoxaparinum. În ziua 6 de la internare se efectuează o nouă puncție lombară, care a arătat o evoluție favorabilă a reacției inflamatorii din LCR cu prezența a $1.270 \mathrm{ecn} / \mathrm{mmc}$, dintre care $\mathrm{PMN}=88 \%$. Din cauza persistenței convulsiilor la nivelul hemicorpului drept, care nu au cedat la diazepam, şi a agitației psihomotorii, la care s-au asociat ulterior lipsa de cooperare şi alterarea statusului mental (comă scor Glasgow 4-5), pacientul a fost admis în terapie intensivă pentru supraveghere, timp de 4 zile. În acest timp, deficitul motor s-a ameliorat, iar coma s-a superficializat. Tratamentul antibiotic administrat a rămas sub aceeaşi schemă. A fost readmis pe secție, unde a prezentat halucinații vizuale, dar care s-au remis spontan.

După 12 zile, s-a oprit tratamentul cu meropenem şi s-a reintrodus cefotaxim. O nouă puncție lombară în ziua 18 de la internare a relevat LCR clar cu $10 \mathrm{ecn} / \mathrm{mmc}$, iar hemoleucograma a fost în limite normale: $\mathrm{GA}=7.380 / \mathrm{mmc}, \mathrm{PMN}=60,4 \%$, $\mathrm{PCR}=<6 \mathrm{mg} / \mathrm{l}, \mathrm{VSH}=40 \mathrm{~mm} / \mathrm{h}$.

Pacientul s-a externat ameliorat, în ziua 33 de spitalizare, cu stare generală bună, orientat temporo-spațial, cooperant, fără erupție cutanată, cu dureri intermitente la nivelul membrului inferior drept, dar cu forţă şi mobilitate păstrate.

\section{DISCUTुII}

Cazul de față a fost abordat ca un caz de TVC, iar iniţierea tratamentului anticoagulant asociat $\mathrm{cu}$ tratamentul antibiotic şi simptomatic a determinat o evoluție favorabilă.

Considerat ca TVC asociată meningitei, cazul prezentat susține datele din literatura de specialitate referitoare la dinamica necesară diagnosticării unui astfel de caz. Evoluția rapidă, cu fenomene neurologice de focalizare, subliniază necesitatea monitorizării prin repetarea examenelor imagistice chiar dacă, la evaluarea LCR, aspectul este cel al unei meningite purulente refractare, cu creşterea leucocitelor şi neutrofilie, în cazul pacienților cu evoluție nefavorabilă.

Aşadar, este cunoscut că TVC afectează persoanele tinere şi copii mai frecvent decât oricare alt tip de accident vascular. În copilărie există o incidență 
crescută a TVC în rândul nou-născuților față de celelalte categorii de vârstă (3), iar pacienții sunt predominant de sex feminin (2), aspecte neprobate de cazul nostru.

TVC se poate produce în sistemul venos superficial sau profund şi sinusurile venoase. Sistemul venos superficial este implicat mai frecvent (76\%-86\%) comparativ cu sistemul venos profund (14\%-38\%). Există diferențe anatomice care fac sistemul venos superficial mai susceptibil la tromboză. Subdiagnosticarea implicării sistemului venos profund se poate datora şi dificultăţii radiologice în identificarea trombozei la acest nivel.

TVC este asociată cu multiple afecțiuni acute şi cronice. Acestea condiții includ febra, infecțiile, deshidratarea, anemia, precum şi afecțiuni acute sau cronice precum lupusul eritematos, boala renală, leucemia, condițiile hematologice şi bolile congenitale de inimă (4). Totuşi, după Carpenter et al., un procent între 23 şi $65 \%$ dintre copii au fost raportați ca fiind sănătoşi înainte de diagnostic (5).

Trombofilia, genetică sau dobândită, reprezintă un important factor de risc. Experții recomandă evaluarea pentru trombofilie a tuturor copiilor $\mathrm{cu}$ TVC independent de alți factori de risc deja stabiliți. În ciuda acestei recomandări, doar puține cazuri au fost raportate ca având o evaluare protrombotică. Numărul de pacienți cu TVC şi un factor de risc identificat pentru trombofilie variază de la studiu la studiu. Procentul este între 33\% şi 99\%. Acest procent ar trebui interpretat cu precauție deoarece studiile sunt prea mici pentru a avea putere statistică (5).

Cauzele infecțioase de tromboză sunt în scădere, dar în țările în curs de dezvoltare totuşi infecțiile sistemice şi infecțiile de sistem nervos central rămân o cauză importantă de TVC. Cele mai comune infecții asociate cu tromboza sunt otita, mastoidita, sinuzita (2). Meningita se poate complica prin TVC, aspect ce potențează dificultatea diagnostică, acesta fiind un motiv pentru care incidența rămâne subestimată (4). Dacă meningita este suspectată, este necesară efectuarea unei puncții lombare înainte de a începe anticoagularea sau anticoagularea trebuie oprită temporar (2). Meningita pneumococică este asociată cu complicații intracraniene, care se întâlnesc la aproximativ $74,7 \%$ dintre pacienții adulți, dintre care $9,2 \%$ dintre cazuri sunt reprezentate de TVC (6).
Heller et al. (7) au raportat trauma ca un factor de risc în $6,7 \%$ dintre copiii cu TVC. Studiile efectuate au arătat că tromboza asociată traumei se întâlneşte mai frecvent în sinusul transvers sau sagital superior, dar fără a exista o corelație cu severitatea leziunii (5).

Ca factor de risc din cei menționați în literatura de specialitate, pacientul nostru era cunoscut $\mathrm{cu}$ anemie, iar pentru trombofilie nu a fost investigat. Probabilitatea procesului trombotic poate fi inserată în contextul infecțios al meningitei. De asemenea, din datele anamnestice nu s-a raportat nici un traumatism cranian.

Simptomatologia clinică în TVC tinde să varieze în funcție de vârstă şi de factorii asociați. Nounăscuții şi copiii mici prezintă cel mai adesea convulsii şi letargie. Copiii mai mari prezintă în special simptome ale creşterii presiunii intracraniene precum cefalee, vărsături, alterarea statusului mental. Cefaleea este cel mai frecvent simptom, de obicei primul, poate fi şi singura manifestare. Tot la aceştia din urmă se pot întâlni şi semne neurologice focale (hemipareză, paralizie de nervi cranieni) şi convulsii (5). Coma poate fi întâlnită ca un simptom la prezentare în $28 \%$ dintre copiii cu TVC (3).

Simptomatologia la pacient a fost interpretată în contextul meningitei. Instalarea deficitului motor în ziua 10 de boală a determinat efectuarea unui nou CT. Imagistic s-a ridicat suspiciunea de tromboză de sinus transvers stâng cu persistența edemului cerebral difuz.

Deficitul motor, alterarea statusului mental şi convulsiile pot pleda în favoarea unei complicaţii prin TVC, deoarece paraclinic reacția inflamatorie din LCR era în scădere, cum s-a demonstrat în ziua 6, dar starea clinică a pacientului se înrăutățea vizibil prin asocierea simptomelor menţionate.

Diagnosticul clinic de TVC este dificil de făcut şi se bazează pe metode neinvazive. Metodele curente de diagnostic includ CT, CT venograma, MRI, MR venograma, angiograma convențională sau Doppler transcranial. Angiograma convențională este considerată ,the gold standard“, însă CTul rămâne cel mai utilizat $(5,8)$. La cazul nostru, examenul imagistic diagnostic a fost CT-ul.

O întrebare care decurge într-un mod logic din improbabilitatea diagnosticului imagistic este de ce nu s-a recurs la o investigație suplimentară cu specificitate superioară în diagnosticul TVC, dintre 
cele tocmai menționate. Răspunsul nu poate fi decât unul: accesul redus la metode de diagnostic suplimentare şi costisitoare, susținute pe considerentul unei țări în curs de dezvoltare. Acest lucru face ca simțul clinic al medicului curant să cântărească considerabil la granița dintre patologii, în evaluarea unui caz clinic.

Principalul tratament în TVC constă în anticoagulare şi tratament suportiv. De asemenea, tratamentul adecvat al infecției, deshidratării, febrei, presiunii intracraniene crescute, convulsiilor, anormalităților presiunii sangvine, hiper sau hipoglicemiei poate avea un impact semnificativ (4).

În fond, abordarea cazului nostru ca o TVC asociată meningitei presupunea ca măsură terapeutică introducerea medicației anticoagulante în contextul în care pentru această abordare nu exista susținerea imagistică certă. Problematica ridicată de acest caz se concentrează pe ipoteza conform căreia dacă medicația anticoagulantă poate aduce un beneficiu pacientului sau dimpotrivă, un prejudiciu medicului curant aflat în improbabilitate diagnostică, printr-o evoluție ulterioară nefavorabilă a stării clinice a pacientului.

Anticoagularea poate fi un tratament efectiv al TVC şi este bine tolerată de către copii. Beneficiul anticoagulării este recanalizarea vasului ocluzat, limitarea propagării cheagului existent precum şi formarea de alți trombi cu prevenția embolismului pulmonar. Acest beneficiu trebuie să fie câştigat împotriva riscului de hemoragie $(7,9)$. Eficacitatea anticoagulării a fost evaluată în doar două studii randomizate mici. $\mathrm{Cu}$ toate inconvenientele aferente acestor studii, s-a demonstrat un oarecare beneficiu al anticoagulantelor în tromboza venoasă intracerebrală şi, poate cel mai important lucru, s-a demonstrat siguranța administrării tratamentului anticoagulant la pacienți (10).

Pacientul nostru a beneficiat de antibioterapie care să includă în spectrul antimicrobian S. pneumoniae, rezistent la penicilină, dar şi un eventual stafilococ, microorganism cunoscut cu cele mai multe asocieri cu fenomenele trombotice (10). De asemenea, a primit tratament anticoagulant cu enoxaparinum. Evoluția ulterioară, consecutivă măsurilor terapeutice în ansamblu, a fost lent favorabilă, cu ameliorarea deficitului motor şi superficializarea comei.

\section{CONCLUZII}

Complicația relativ rar descrisă în literatură TVC asociată meningitei cu Streptococcus pneumoniae - nu trebuie să influențeze decizia terapeutică bazată pe simțul clinic, cu atât mai mult cu cât este raportat ca fiind o patologie subdiagnosticată. Evoluția ulterioară a fost lent favorabilă, cu remiterea simptomatologiei, demonstrând că raționamentul creierului uman format în ani de experiență nu poate fi încă tehnologizat, cu atât mai puțin înlocuit de vreun robot, iar existența unor seturi de reguli de tratament care nu pot acoperi niciodată varietatea de particularități ce se poate întâlni în practică trebuie pusă întotdeauna la îndoială. 